\title{
Review on Evidence Based Ayurvedic Treatment Practices for Psoriasis
}

\author{
Review Article
}

\section{Venkateshwarlu B ${ }^{1^{*}}$, Anumol K ${ }^{1}$, Mithuna Mohan ${ }^{1}$, Priyanka Bai ${ }^{2}$, Murali Krishna ${ }^{1}$, Babu $\mathbf{G}^{3}$}

\section{Research Officer, 2. Senior Research Fellow (Ayurveda), 3. Assistant Director In-charge,} Regional Ayurveda Research Institute for Skin Disorders, Vijayawada

\begin{abstract}
Psoriasis is characterized by sharply defined erythematous squamous lesions. It is one of the commonest chronic, non-infectuous papulo-squamous disorder of the skin. Several treatment modalities are in existence in modern system of medicine; however they have limitations due to their side effects due to long time use. Considering this, search for new safe therapeutic regime in psoriasis is going on. The present paper presents some of the promising evidence based Ayurvedic therapeutic approaches in the management of psoriasis.
\end{abstract}

Keywords: Psoriasis, Ayurveda, Kitibha, Evidence based medicine.

\section{Introduction}

Psoriasis is one of the commonest chronic, noninfectious papulo squamous disorder of the skin, characterized by sharply defined erythematous squamous lesions. It is an immune-mediated and is not contagious disorder. Psoriasis is a recurring condition which varies in severity from minor localized patches to complete body coverage. The causative factors of Psoriasis are not known, but it is believed to have a genetic component. Certain factors like stress, excessive alcohol consumption and smoking are thought to aggravate psoriasis.

\section{Aetiology of Kustha}

Psoriasis is come under Kshudra Kushta. The following are the aetiology of Kshudra Kushta and Kushta.

a. Intake of contradictory food and drinks, which are liquid, unctuous and heavy

b. Suppression of urges (vomiting and other natural urges)

c. Do physical exercise in excessive heat and after taking heavy meal

d. Use of cold water immediately after exposure to the scorching sun, exertion

e. Intake of uncooked food and transgression of the procedure of Panchakarma

f. Do sexual act in the state of indigestion, sleep during the day time

Ekakushtha is one among the Kshudra kushtha can be considered as Psoriasis in modern parlance,

\section{*Corresponding Author:}

\section{Venkateshwarlu B}

Research Officer,

Regional Ayurveda Research institute for skin disorders, Vijayawada-520015

Email: drcvenkat@rediffmail.com
Some of the scholars opined the Psoriasis as Kitibhakushta. Ekakushtha is a Vata-Kapha predominant disease, Some authors attributed Aswedanam (lack of sweating), Mahavastum (thick skin), Matsya shakalopamam (scaly exfoliation like fish scale), Krishna Aruna Varna (blackish or reddish discoloration of skin) which are typical sign \& symptoms described under Kushtha Rogas. It is a dry, well-circumscribed, genetically determined, inflammatory and proliferative disease occurs in both the sex.

Lavanayukta kichidi (salt added mashed vegetables with rice), milk, mithyahara vihara (incompatible food and life style) are mentioned as etiological factors for psoriasis. Multi factorial origin trauma, acute infection with inflammation, genetic predisposition, psychological upsets, infection are precipitating factors in developing psoriasis. Apathya ahara, vihara (incompatible food and life style), psychological stress aggravates the disease condition.

Exudative skin patch, round, thick, and have severe itching, unctuous and black patch is known as Kitibha. Whereas, entire body becomes blackish red in Ekakushta.

\section{Treatment}

When disease is localised to skin, purification measures like Vamana (therapeutic emesis), Virechana (therapeutic purgation) and external applications (lepa) should be done. When, Rakta dhatu (blood) is involved, purification measures, lepa (ointment) and kashayas (decoctions), Raktamokshana (bloodletting) are indicated. The above measures and arista (fermented medicaments) is indicated when mamsadhatu is involved. This disease becomes chronic when medodhatu (fat) is involved.

Among these, shodhana (purification measures) is essential, Agnideepana (appetizers), Amapachana (digetstants), Vamana (therapeutic emesis), Virechana 
(therapeutic purgation), Raktamokshana (bloodletting) are the treatment options for psoriasis.

All kinds of skin diseases are termed as Kushta in Ayurveda. Shali (type of rice), Sasthtika dhanya (rice), Yava (Barley), Godhuma (Wheat), etc. are useful in Kushta (13). Vajrakataila is best for anointing and for massage. Khadira kashaya (decoction made from Acacia catechu) for drinking and for tub bath are useful in skin diseases.

Incompatible food, over eating, uncooked food, vidahi (food causing burning sensation), abhishyandhi ahara (food causing obstruction to the channels), and day sleep should be avoided by the skin disease patients (14).

In all kinds of Kushta, Tuvaraka taila and Bhallataka taila are effective.

In modern medicine, symptomatic relief and to slow down the disease progression and development of deformities are the main aims of the treatment.

Though, certain drugs are effective in modern medicine, liver scare of methotrexate, mutagenic potentials of PUVA, skeletal toxicity of retinoid and systemic and local side/ toxic effect of corticosteroids necessitate search for newer and safer drugs (15).

\section{Aims and objectives}

This study aimed to identify and compile the single and compound formulations/regimes having the beneficial effects on psoriasis and to identify the promising drugs, which have shown effective in clinical trials.

\section{Materials and methods}

Considering the above, clinical studies conducted Ayurvedic drugs on psoriasis have been collected and reviewed for their effectiveness.

\section{Observations}

The following observations are made by reviewing the clinical trials.

Various therapeutic procedures like Snehana (oleation), Sweda (sudation), Vamana (therapeutic emesis), Virechana (therapeutic purgation), Jalukacharana (bloodletting) are very effective in psoriasis. Plain Goghrita, Vajraka ghrita, Panchatiktaka guggulu ghrita are the common snehapana dravya (oleation). Trikatu churna is used as deepana (appetizer) and pachana dravya (digestant) before snehapana (oleation). Snehapana with Vajraka ghrita is found more effective for snehapana in comparison to plain Goghrita (3).

External applications viz., Aloe vera gel, Aragwadha kera, Chakramarda lepa, Chakramarda kera taila, Jeevanthyadi yamaka, Dineshavalyadi taila, Daryadi Yamaka Malhara, Kutaja Suryapaka Taila, 5\% Semicarpus anacardium ointment etc. are useful and found therapeutically effective in clinical trials (5-15).

External application of Aloe vera gel is very much useful in Psoriasis. It is cooling, astringent and useful in various skin disorders. In a clinical study, Aloe vera gel alone found more effective than to $1 \%$ triamcinilone acetonide ointment (2).
Nimba (Neem- Azadirachta indica A.Juss.) is an important medicinal plant useful in various infectious diseases and skin diseases. Leaves, bark, seed and seed oil are the main useful parts of Nimba. Nimbidin is an important active ingredient of Nimbataila (seed oil of Nimba). $200 \mathrm{mg}$ of nimbidin in capsule form along with Aragwadha kera is found effective in psoriasis (4).

Seeds of Chakramarda (Cassia tora L.) are very effective in both Svitra and Kitibha. External application of paste made of Chakramarda seeds found more effective than deprovate ointment (5).

Similarly, Guduchi ghana, Arogyavardhini vati, Daruharidra kvatha, Kaisora guggulu, Eranda bhrishta Haritaki, Navayasa Rasayana leha etc. are effective when administered orally.

\section{Conclusion}

Hence, it can be concluded that some of therapeutic regimes mentioned and practiced in Ayurveda are time tested and showing promising results, when these regimes are judiciously used. Certain specific Ayurvedic practices like Deepana, Pachana, Snehapana, Swedana, Vamana, Virechana, Jalukavacharana along with other oral and topical medicaments certainly helpful in psoriatic patients.

\section{References}

1. Paulsen E, Korsholm L, Brandrup F, A doubleblind, placebo-controlled study of a commercial Aloe vera gel in the treatment of slight to moderate psoriasis vulgaris, Journal of the European Academy of Dermatology and Venereology, Volume 19, Issue 3, May 2005, Pages 326-331.

2. Choonhakarn C, Busaracome P, Sripanidkulchai B, Sarakaran P, A prospective, randomized clinical trial comparing topical aloe vera with $0.1 \%$ triamcinolone acetonide in mild to moderate plaque psoriasis, Journal of the European Academy of Dermatology and Venereology, Volume 24, Issue 2, February 2010, Pages 168-172.

3. Rohini Salve, Efficacy of Goghrita and Vajrak ghrita as Abhyantar sneha in the management of Ekkushtha with special reference to Psoriasis through Vaman: A comparative study, International Journal of Research in Ayurveda \& Pharmacy, 2014, Vol. 5, Issue 3, Pages 284-289.

4. Pillai B.K.R., Amma K.C.B., Nair S.S., Pillai N.G.K. and Nair C.P.R., The effect of Nimbathiktha (Nimbidin) In Kitibha (Psoriasis) A double blind Clinical study, Journal of Research in Ayurveda and Siddha, Vol. XXIII. No. 1-2 (2002) Pp. 42-50.

5. Anita Sinha, Dash N. C. and Das B. K., A Study on Kitibha (Psoriasis) and its Management with a Herbo-topical Application, Journal of Research in Ayurvedic Sciences, Vol. XXXI. No. 4, Oct-Dec 2010, Pp. 59-70.

6. Maheswar T, Panigrahi H, Bharti, Babu G, Seema Jain, Rakesh Rana, Richa Singhal, Srikanth N, Padhi M M, Dhiman K S, Clinical evaluation of Vajraka ghrita, Arogyavardini vati 
and Dineshvalyadi taila in the management of Kitibha (Psoriasis), Journal of Research in Ayurvedic Sciences, Vol. XXXVII. No. 1-4, 2016, Pp. 38-53.

7. Kalpana Galani, Vyas S. N., Dave A. R., A Clinical study on Role of "Saptasamo Yoga and DarvyadiYamak Malahara" in the management of Ekakushtha (Psoriasis), AYU, Vol. 30, No. 4 (October-December) 2009, Pp. 415-420.

8. Tanweer A. Syed, S. Ashfaq Ahmad, Albert H. Holt, Seyed Ali Ahmad, Seyed Hamzeh Ahmad, and Moharnmad Afzal, Management of psoriasis with Aloe Vera extract in a hydrophilic cream: a placebo-controlled, double-blind study, Tropical Medicine and International Health, volume I, No. 4, August 1996, Pp. 505-509.

9. Gond Pushpa, Rekha Rani, Shringi M. K., Role of Leech therapy and Panchatikta ghrita in the management of Psoriasis, International Ayurvedic Medical Journal, Volume 1; Issue 3; May - June 2013, online journal.

10. Mahesh Sharma M, Gajanana Hegde, Mythrey R C, A comparative clinical study on the management of Psoriasis w.s.r. to Ekakushta, International Journal of Research in Ayurveda and Pharmacy, 2013, Vol.4, Issue 1, Pages 8489.

11.Bharti Umretia, Patgiri B.J., Prajapati P.K., Ravishankar B., A Comparative Clinical Study of Guduchi Ghana Prepared by Kwatha and Aqeous Extract on Ekakustha, Journal of Ayurveda, Vol.III, No.3, Jul-Sep2009, Pages 22-30.

12. Mahesh Verlekar, Smruti R. Nagvenkar, Mahesh Chandra Sharma, Effect of Semecarpus anacardium Linn. (Bhallataka) in the management of skin diseases w.s.r to Psoriasis, Journal of Ayurveda, Vol.1I, No.4, Oct-Dec 2008, pages $84-88$.

13. Srikantha Murthy K.R., Sushruta samhita, Vol.II, Reprint 2008, Chaukhamba Orientalia, Varanasi, Sutrasthana 9/5.

14. Srikantha Murthy K.R., Sushruta samhita, Vol.II, Reprint 2008, Chaukhamba Orientalia, Varanasi, Sutrasthana $9 / 4$

15.Singh O.P., Rai N.P. and Pathak N.N., A comparative clinical evaluation of Daruharldra in the management of Kitibh (Psoriasis), Journal of Research in Ayurveda and Siddha, Vol. XXIII. No. 3-4, 2002, Pp. 31-37.

16.Singh O.P., Padhi M.M., Das B., Deep V.C., Hazra J., Alam M.M., Tewari N.S. and Rao M.M., Clinical evaluation of Arogyavardhini vati, Kaishore guggulu and Chakramardakera taila in the management of Kitibh (Psoriasis), Journal of Research in Ayurveda and Siddha, Vol. XXVIII. No. 1-2, 2007, Pp. 61-71.

17.Akhil N.Parida, Bhatt N.N., Dave A. R., Shukla V. D., A Comparative Study of Vamana \& Virechana karma in Ekakushtha w.s.r to Psoriasis, AYU, Vol. 30, No. 3, Jul-Sep 2009, Pp. $255-259$.

18. Charmi S. Mehta, Alankruta R. Dave, Shukla V. D., A clinical study of some Ayurvedic compound drugs in the assessment quality of life of patients with Eka Kushtha (psoriasis), AYU, Vol. 32, No. 3, Jul-Sep 2011, Pp. 333 - 339. 